\title{
REVIEW
}

\section{NATURE VALUE: THE EVOLUTION OF THIS CONCEPT}

\author{
Valor da natureza: a evolução desse conceito
}

\author{
Sabrina Soares da Silva ${ }^{1}$, Ricardo Pereira Reis ${ }^{2}$, Patrícia Aparecida Ferreira ${ }^{2}$
}

\begin{abstract}
More attention has been paid to environmental matters in recent years, mainly due to the current scenario of accentuated environmental degradation. The economic valuation of nature goods can contribute to the decision-making process in environment management, generating a more comprehensive informational base. This paper aims to present, in a historic perspective, the different concepts attributed to nature goods and were related to the current predominant perspectives of nature analyses. For this purpose, this paper presents the different concepts attributed to value since the pre-classical period, when nature were viewed as inert and passive providers of goods and services, this view legitimized nature's exploration without concern over the preservation and conservation of nature. The capacity of nature to absorb the impact of human action appears to be reaching its limit, considering the irreversibility, the irreproducibility and the possibility of collapse. The appropriate method for valuing natural resources is not known, but more important than the method is to respect and incorporate the particular characteristics of the nature goods into this process. These characteristics must be valuated in order to arrive at a more consistence approach to nature value and promote sustainability.
\end{abstract}

Index terms: Valuation, nature goods, environmental analyses.

\section{RESUMO}

Nos últimos anos, mais atenção tem sido dada às questões ambientais, principalmente decorrente do atual cenário de acentuada degradação. A avaliação econômica dos recursos naturais pode contribuir com o processo de tomada de decisão na gestão ambiental, gerando uma importante base de informações. Neste artigo, buscou-se apresentar, em uma perspectiva histórica, os diferentes conceitos atribuídos ao valor dos recursos naturais e como eles se relacionam às perspectivas atuais de análise ambiental. Com essa finalidade, foram apresentados os conceitos atribuídos ao valor desde o período pré-clássico, quando a natureza era vista como fornecedora inerte e passiva de produtos e serviços, visão que legitimou sua exploração, sem considerações quanto à sua preservação e conservação. A capacidade da natureza de absorver o impacto das ações humanas parece estar chegando ao seu limite, em razão da irreversibilidade, irreprodutibilidade e possibilidade de colapso. Não se conhece um método totalmente apropriado para se avaliar os recursos naturais, porém, mais importante seria respeitar e incorporar as características particulares dos recursos naturais nesse processo. Essas características devem ser valoradas, a fim de se chegar a uma aproximação mais consistente do valor da natureza e promover a sustentabilidade.

Termos para indexação: Valoração, recursos naturais, análises ambientais.

(Received in february 13, 2012 and approved in february 27, 2012)

\section{INTRODUCTION}

More attention has been paid to environmental matters in recent years, mainly due to the current scenario of accentuated environmental degradation. This situation stimulates the necessity of changes in our standards of production and consumption, and the consideration of the impact of human action on nature before making decisions. To support these decisions, it is necessary that the decision-makers have appropriate information about the advantages and disadvantages of human actions affecting the environment.
The economic valuation of nature goods can contribute to decision-making processes in environment management, generating a more comprehensive informational base (TURNER et al., 2003). This is not the only parameter, but is an important assessment to other qualitative and quantitative assessments on ecosystem functions. It is also an effective way to convince decisionmakers of the value of preserving the ecosystems.

The concept of value, particularly the value of nature goods, has been given different meanings in different periods of the economic history. In different periods, we

\footnotetext{
'Universidade Federal de Lavras/UFLA - Departamento de Administração e Economia/DAE - Cx. P. 3037 - $37200-000$ - Lavras - MG - Brasil sabrinasilva@dae.ufla.br
}

2Universidade Federal de Lavras/UFLA - Departamento de Administração e Economia/DAE - Lavras - MG - Brasil 
can observe that the particular characteristics of nature goods are not considered when we are attributing value to them. Actually, even today, researchers know just a little about nature and its characteristics, and nature is often treated like any other marketable good that is reproducible, or as a free good. Some of the nature characteristics, relevant in the valuation process, are presented by DASGUPTA (2008): the depreciation of natural capital is usually irreversible or takes a long time to recover; it is impossible, except in a limited sense, to replace a depleted or degraded ecosystem; and ecosystems can collapse abruptly.

The neoclassical and the ecological views, despite presenting different views, represent today the main perspectives in the analysis of nature. There are differences between these perspectives: while the neoclassical one proposes growth models in which technological progress, the accumulation of reproducible and human capital would be able to substitute the natural resource base, generating indefinite growth in output, in the form of material goods and services, the ecological view reveals that the problem is that nature consists of degradable resources and is, in many aspects, fragile (DASGUPTA, 2008). However, many of the assumptions of these perspectives are based on concepts developed years ago.

In this way, this paper aims to discuss, in a historic perspective, a review of the different concepts attributed to value of nature goods. In the description of each concept there is an outline of how they are inserted in the historical context, were influenced by previous authors and were related to the current predominant perspectives of nature analyses. This paper argues that treating nature as a free good and as reproducible is something that contributed to its degradation and this idea would not be tolerable in the current context.

\section{PRE-CLASSICAL THOUGHT}

The origin of the word 'value' comes from the Latin valere, meaning to be strong, to be well, and to be worth. But this word has been given different meanings and there is no singular sense for it. The treatment of nature value by pre-classical, classical and neo-classical authors support the understanding of the evolution of human thinking about it.

Karsten (1987) discusses some of the early authors' perspectives. Aristotle (384-322 BC) is cited as a starting point for value analyses. An important contribution of Aristotle was the foundations of the concepts of the use value and exchange value, which were the two characteristics of every commodity (SCREPANTI;
ZAMAGNI, 2005). The use value, i.e., the goods ability to satisfy a specific need, reflects man's interrelationship with nature and refers to its role in sustaining the human life. This relationship is expressed by people's desire to obtain goods from nature and by nature's ability to produce things for people (HOLLY, 2006; KARSTEN, 1987). The exchange value is related to the price of a good, or the quantity of money that people are willing to pay for this good. These concepts are used today to analyze the natural resources value. Utility was widely held as the value determinant and only few theorists took note of the production cost (FOGARTY, 1996). This is similar to the nature neoclassical view, because there are no preoccupations with a minimum natural capital stock.

A few centuries later, the feudal economy became predominant and brought some modifications to society (SCREPANTI; ZAMAGNI, 2005) and the advent of Christianity (JOHANSEN, 1999). Two Christian philosophies were considered important in the Middle Age for their contributions to the value theory. The first was Aurelius Augustine (354-430), who disagreed with Aristotle in his idea about use value. For him, there was a difference between natural value and use value, or either, between the natural rational order of things and man's use of things, based on their individual utility. This use was presented as the negation of the nature value, and there could be a conflict between man's action and the nature requirements. It was the first time that man's valuation of the physical environment was associated with the destruction of nature and, in consequence, of man's life.

Augustine showed concern over the impact of human action on nature, being contrary to the logical exploitation predominant in his epoch. He presented the idea of a conflict between the use value, which had the same sense presented by Aristotle, and the natural value, which had no link with the human use of the nature and was an early expression of the intrinsic value of nature. However, today many economists do not agree that nature has non-anthropocentric or non-economic value, independent of human beings (SIMON, 2002). But some ecological economists share the Augustine view, believing that nature has value that goes beyond that of satisfying human needs and wants.

The second Christian author was Thomas Aquinas (1225-1274), who dealt with relationships between men, including economic relationships, and that between man and God (MEDEMA; SAMUELS, 2003). Aquinas discussed the adequate price, a good property that expresses its intrinsic value, which is associated with the efforts sustained in production and the good capability to 
satisfy a human need. But Aquinas did not explain how this value was determined (SCREPANTI; ZAMAGNI, 2005), he only suggested that labor assumes an important role in the economic values determination (KARSTEN, 1987).

Aquinas did not deal with use value in the same way as the earlier authors, and had a different idea of intrinsic value compared. He used the intrinsic value to refer to the fair price of goods, similar to Aristotle's concept of exchange value, but considering that there was equilibrium in the market. Unlike Augustine, Aquinas believed that no value could be placed on nature and that it was a free good. God was used to justify the nature exploration and to exempt men from any responsibility for the nature conservation and restoration. This view legitimizes the intense exploitations and negligence of nature in the Middle Ages in Europe. Like Aristotle, Aquinas too did no believe in any commitment of men with nature, with a minimum natural stock, or with the irreversibility of human action over nature.

A cultural revolution began with Humanism, Renaissance and Scientific Revolution, when man was placed in the centre of universe. With this change, the utilitarianism was applied by Bernardo Davanzati (15291606), who attempted to construct a utility theory of value, concentrated on the goods demand determinants, and the merchants' profits, that dependent on exploiting the difference between the buying and selling prices and the production process. Davanzati argued that the goods value depends on their utility and rarity. In this way, the effect of greater scarcity would increase the use value of the goods and the price at which they could be sold (FOGARTY, 1996; SCREPANTI; ZAMAGNI, 2005).

Davanzati had the same utilitarist view as Aristotle and Aquinas, but he brought a new factor that influences the value of a good: scarcity. This factor is still used today and is considered an important parameter in estimating the goods value. But Davanzati also had no concern with a minimum stock of resources that must be preserved, like the neoclassical view of nature, or preoccupations with the irreversibility of human action on nature and the irreproducibility of the nature goods. He was in accord with the view of his epoch, in which man was the center of the universe and nature value was related with human needs and wants.

In the seventeenth century, according to Screpanti and Zamagni (2005), even if still under the influence of mercantilism, some economists began to distance themselves from it and to lay the foundations for the emergence of the classical political economy. Following a Cartesian philosophy of deduction, they broke away from the dominant mercantilist utility view and looked for a solution in the cost of production (FOGARTY, 1996). The Englishman William Petty (1623-1687), was one of the most important authors in this perspective.

Petty saw nature (land) and labor as sources of wealth and value, components that would be used to measure the value of products (KARSTEN, 1987). He abandoned the subjective theory of value and reintroduced the concept of natural value, in which the commodities prices would tend to adjust to this value by means of small oscillations (SCREPANTI; ZAMAGNI, 2005). Petty was an important author of the physiocratic school of economic thought, that was based in the idea that the nations wealth was derived from the value of agriculture and land development. He believed in a permanent regeneration of the natural environment, which would influence the growth and productiveness and allow the permanent restoration of the production conditions.

Petty saw nature as a value source, admitting that nature has use value and exchange value, as Aristotle had classified. The idea of natural value is rethought, but differently from what had been proposed by Augustine. The natural value was not seen by Petty as a kind of intrinsic value, but it was seen, like Aquinas, as a fair price, in a kind of equilibrium condition. However, although Petty adopted a more rational perspective of the value, he did not abandon the utility view of nature, which was in accordance with the epoch, in which the accumulation of capital and profits were the most important objectives. His perspective is similar to the neoclassical one because he was not concerned with the natural capital stock. Petty also had no concern with the irreversibility or irreproducibility of the nature goods.

In the eighteenth century there were important political, economic, social and cultural transformations that caused changes in economic thought. The classical political economy was influenced by these changes, and human relationships came to be seen as regulated by objective mechanical laws (SCREPANTI; ZAMAGNI, 2005). In this period, there were some difference between the view of the economists that lived on the continent and those who lived in England: on the Continent, the reactions against mercantilism assumed the form of agrarian protectionism; to the English, wealth was made up of accumulated capital and gold, the results of trade and industry. The latter characterized the economic thought in the region and epoch in which Richard Cantillon (1680?1734) lived and developed his value theory.

Cantillon offered an explanation of wage differentials which anticipated that of Smith: it depended 
on differences in the cost of training workers, in the risks of different types of job and the levels of loyalty and responsibility required by the jobs (FOGARTI, 1996). Cantillon, like Petty, adopted a more rational perspective of value, but they differed in one point: Cantillon attributed great importance to the land in his definition of value, incorporating the influence of the region, while Petty used labor. Cantillon made a distinction between intrinsic value, which differed from the concept of Aquinas, because it was more concerned with the production process rather than commerce, and the market price, which assumed a kind of equilibrium between supply and demand, which was based on the idea of Petty (natural value) and Aquinas (intrinsic value). But nature value was, like in all the preclassical period, except the Augustine view, limited to the utility that it had in satisfying human needs and wants.

François Quesnay (1694-1774), also a member of the physiocratic school, believed that the basic determinant of value was to be found in nature, which was a nature theory of value (KARSTEN, 1987). Quesnay used the same logic as Petty and Cantillon, adopting nature as the source of value, but with the predominance of a utility view, in which the role of nature was only to create value for humans, and there was no concern with the conservation and restoration of nature or the irreversibility of the human action.

Also in the eighteenth century, Ferdinando Galiani (1728-1787), anticipating William Jevons and Carl Menger, developed a theory of utility value and, implicitly, described the notion of diminishing marginal utility (FOGARTY, 1996). He believed that value depended on the goods utility and scarcity and argued that value was not an intrinsic quality of goods, but a quality that stemmed from the economic actors choices. Galiani recovered the Davanzati theory of value, in which the value would depend on utility and scarcity. But he advanced this perspective by assuming that the value is not intrinsic to each good, but will depend on individual choices. Reality would be constructed and the value does not exist by itself, but it is attributed by individuals to the goods. It is, still today, used to explain nature value.

\section{THE CLASSICAL THOUGHT}

The English Classical Political Economy was the dominant school of economics from the late eighteenth century until the end of the nineteenth century, being the first major school to explicate the modern market and the capitalist economy (MEDEMA; SAMUELS, 2003). One of the most important authors was Adam Smith (1723-1790). Smith (2011) argued that the word 'value' had two meanings: the value in use, that expresses the utility of some particular object, and the value in exchange, that expresses the power of purchasing other goods which the possession of the object transmits. In this way, goods that have the greatest value in use, will frequently have little or no value in exchange, like water; and, those goods which have the greatest value in exchange, will have little or no value in use, like diamonds.

Smith retook Aristotle's concepts of value, which were divided into use value and exchange value. However he used these concepts to provide a solution to the diamond-water paradox, which it leads one to believe that nature has no value. He also goes against the earlier authors, who had believed that price was related to utility, defending that the single most important factor in determining the price of a good was labor. In Smith's thinking, nature, which has no value, must have no price too, what is in accordance with the epoch in which more people became active in the economy, with the increasing importance of the middle class, and no room for discussions about the nature preservation.

After French Revolution and Napoleonic wars began the Age of Restoration. It was in this period that David Ricardo (1772-1823) lived. In his discussions about value, Ricardo (2010) sought to continue Smith's theory, and concluded that the commodity value would be the quantity of any other commodity for which it could be exchanged, which would depend on the quantity labor that would be necessary for its production, and not on the higher or lower price paid for this labor. Nevertheless, scarcity would also be important in determining the exchangeable value of a commodity, while its utility was not a measure of exchangeable value. Therefore, natural resources would only have exchange value after becoming scarce.

Ricardo's thinking was similar to that of Smith. Both considered that the labor used to produce a good was important when it came to attributing value to it, the utility has no importance when defining a value of a good, and nature has no, or little, value. Their theories reflected the thinking that the economy must expand, giving less importance to agriculture or land, and more importance to other activities developed by the middle class. Therefore, the nature exploitation, without any concern for its conservation and restoration, was legitimated by the predominant world view that saw nature as a source of free and unlimited resources.

Jean-Baptiste Say (1767-1832) was another important economist in this epoch. Associating value with the exchange value, Say (2010) wrote that only when other 
people are willing to give in exchange a certain quantity of other goods for the purpose of obtaining a specific good it may be said that it have any worth or value.

Say retook the association between utility and value, which was not considered by Smith or Ricardo. The value humans attach to objects would be originated from the use that they can make of them. Say also gives an alternative solution for the use value and exchange value relationship: while Smith believed that as greater use value represents lower exchange value, Say believed that these values had a direct relation, in which greater use value represents greater exchange value. The utility as a determinant of the value of a good can be associated as the conception adopted by the neoclassicals today. Say also made no reference to the capital natural stock, or the particularities of the characteristics of nature.

After the defeat of the 1848 revolutions and the repression of the workers' movement, favorable technological and cultural preconditions for economic growth and an increase in capitalism were created. The dominant economist of the Age of Capital was John Stuart Mill (1806-1873). Mill (2010) retook Smith's discussion about value, disagreeing with him when he said that things which have the greatest value in exchange, like diamonds, may have little or no value in use. For him, the use of a thing, in political economy, means its capacity to satisfy a desire, or serve a purpose, and diamonds have this capacity in a high degree. Mill (2010) proposed that the exchange value must be distinguished from price, as did Ricardo: price, or value in money, is used to express the value of a thing in relation to money, or the quantity of money for which it can be exchanged. In Mill's vision, according to Perry (1916), the term 'value' is also more general, more elastic and more neutral than 'worth' or 'good'.

Mill's thought was similar to Say's one. Both disagreed with Smith's perspective about the relation between use value and exchange value. Mill believed they were different concepts and cannot be reflected in the price or monetary value of a good. Mill also agreed with Say in the sense that use, or utility, is an important factor in the definition of the value of a good, and in the fact that there are no concerns with the other characteristics of the goods.

\section{MARXAND THE MARGINAL REVOLUTION UNTIL NOW}

In the beginning of the nineteenth century, the middle class started to participate on the transformation of society, polity and economy from a rural/agricultural to an urban/industrial form. However, the working class did not see any change, and the social order continued in the hands of a privileged minority. This was the background for the rise of socialism (MEDEMA; SAMUELS, 2003). The principal theorist of socialism was Karl Marx (18181883). Marx (2010) believed that the value of a commodity has substance, magnitude and form. The substance or origin of value is associated with labor, which rendered apparently incommensurable commodities commensurable. The value magnitude is governed by labor time, but it is secondary to the value substance reality. The value forms serve to translate value, based on economic relations, into concrete properties of things that appear in the exchange sphere and that have two aspects: price and money (HONG, 2000).

These parts of the value explain the distinction and relation between use values and the exchange value. For Marx (2010), the use value exists only when there is use or consumption, and they are the substance of all wealth and the material depositories of exchange value. Marx also showed that the alienation of labor implies in an alienation of nature, but although nature was considered as a prerequisite for production, it was lower than labor. Marx did not explain the importance of nature in his labor theory of value or see that nature participates in the creation of value (KARSTEN, 1987). Marx used the same distinction between use value and exchange value developed by Aristotle, and attempted to explain the value of a good only by the labor used in its production. So the nature has no use value, because no labor is necessary in its production and he does not propose limits to the exploitation of the nature, giving greater importance to manmade goods than to natural goods.

The early 1870 s was a period in which there was a continuation of the process of deep structural change and different economic difficulties that were the first signs of the Great Depression. Carl Menger (1840-1921), one of the greatest economists of this period, proposed that there were different categories of wants or desires, which could be ordered in sequence of desires for successive increments of each good. The intensity of desire for one additional unit declines with successive units of the good: the principle of diminishing marginal utility. If individuals weigh categories, this implies a trade-off between levels of wants (BLAUG, 1997; FARBER; CONSTANZA; WILSON, 2002). But the valuation of needs that cannot be satisfied by the resources at an individual's disposal, like natural goods, are more problematic because the trade-offs between needs will not be possible.

Marginal utility can provide, according Farber, Constanza and Wilson (2002), a basis for explaining exchange value, which is based on use value. However, 
while the classical theorists sought a standard physical commodity unit for measuring exchange value, neoclassical theorists did not need it. As the value can be assumed to be determined by utility on the margin, and the consumers can be assumed to allocate money optimally across uses, the marginal utility of money was the same for an individual in all its uses. In this way, money became the standard unit of measure.

Measures of economic value have the purpose of reflecting the difference that something makes to satisfy human preferences. If something is attainable only at costs, then the difference it makes in satisfying preferences is the difference between its utility and the cost of obtaining it. As the notion of value that guides economic thought is predominantly instrumental, and the value is considered a contribution to a goal, the mental model used is that value is based on want satisfaction, pleasure or utility goals. In this way, the value measurement requires some objective measure of the degree to which the thing improves pleasure, well-being and happiness. This is possible when the economic world is seen as deterministic, moving from one equilibrium to another one, and situations of instability are treated as exceptions. Since individuals can be observed making choices in the marketplace, within the limits of income and time, value measures were developed as imputations from these observed choices. Thus, value is seen as resulting from the expressed tastes and preferences of people, and it is not seen that preferences change over time and under the influence of other factors (FARBER; CONSTANZA; WILSON, 2002).

Even today, the problem of the allocation of given resources among alternative uses lies at the heart of the neoclassical system, which seeks to determine the conditions ensuring the optimal allocation of these resources, based on the scarcity of this resource. It suggests a tendency to extend a basic model to every branch of economic investigation, what was reinforced later, and culminated in the argument of Paul Anthony Samuelson that there is a mathematical function to maximize under constraints that represents a simple principle at the heart of all economic problems (SCREPANTI; ZAMAGNI, 2005)

\section{CONCLUSIONS}

The word 'value' has been given different meanings in different contexts. This is not a new issue, and has been discussed for a long time, but in this process there has never been a consensus in the arguments of economists. Furthermore, the value of nature was not an agreement, but a predominance could be seen of an instrumental view of the nature, in which the only important aspect to be valued were those related to human needs and wants. This view, a consequence of the earlier perspectives of nature, continued in the neoclassical perspective and, with less intensity, in the ecological perspective.

Since the first perspectives, nature has been seen as an inert and passive provider of goods and services. This view legitimized nature's exploration for several centuries, without concerns for its preservation and restoration. Only labor and capital were considered as factors of production, whose costs were important, while nature and its goods were understood as being constantly available and self-regenerating.

The traditionalist statements of the neoclassicists, based in the same utilitarian reductionism of the first economists, in which man is rational, has exogenous preferences and complete information is not enough to explain and propose a solution for current problems. Moreover, the ecological perspective was often limited in its attempt to overcome the neoclassical assumptions. Therefore, most contemporary economists are investing in seeking solutions for the problem of anthropological premises in economic discourse, precisely in defining the economic ontological assumptions, admitting that individuals may be endowed with bounded rationality, endogenous preferences, incomplete information, multiple selves and heterogeneous motivations.

The appropriate method for valuing natural resources is not known, but more important than the method that is chosen to attribute value to the nature resources is to respect and incorporate the particular characteristics of the nature good into this process. These characteristics must be valuated in order to arrive at a more consistence approach to nature value and promote sustainability.

\section{ACKNOWLEDGEMENT}

We would like to thank Dr. Justus Wesseler and the Environment Economics and Natural Resources Group (Wageningen University) for the contribution to this article and Fundação de Amparo à Pesquisa do Estado de Minas Gerais (FAPEMIG) for the financial support.

\section{REFERENCES}

BLAUG, M. Economic theory in retrospect. 5. ed. Cambridge: Cambridge University Press, 1997. 725 p.

DASGUPTA, P. Nature in economics. Environmental and resource economics, Venice, v. 39, n. 1, p. 1-7. 2008. 
FARBER, S.C.; CONSTANZA, R.; WILSON, M.A. Economic and ecological concepts for valuing ecosystem services. Ecological Economics, Amsterdam, v. 41, n. 3, p. 375-392, Jun. 2002.

FOGARTY, M. A history of value theory. The Student Economic Review, Dublin, 1996. Disponível em: < http:// www.tcd.ie/Economics/SER/sq1/ download.php?key=203 > . Acesso em: 23 de jan. 2008.

HOLLY, M. Environmental virtue ethics: a review of some current work. Journal of Agricultural and

Environmental Ethics, Gainesville, v. 19, n. 4, p. 391-424, Aug. 2006.

HONG, H. Marx and Menger on value: as many similarities as differences. Cambridge Journal of Economics, Cambridge, v. 24, n. 1, p. 87-107, 2000.

JOHANSEN, K.F. A history of ancient philosophy: from the beginning to Augustine. London: Routledge, 1999. $685 \mathrm{p}$.

KARSTEN, S.G. Nature in economic theories: Hans Immler traces recognition of the environmental, and its neglect, in various classics. The American Journal of Economics and Sociology, Kansas, v. 46, n. 1, p. 61-70, Jan. 1987.

MARX, K. Capital: A critique of political economy. Seattle: CreateSpace, 2010. 200 p.
MEDEMA, S.G.; SAMUELS, W.J. The history of economic thought: a reader. London: Routledge, 2003. 668 p.

MILL, J.S. Principles of political economy with some of their applications to social philosophy. vol. 1.

Charleston: Nabu Press, 2010. 626 p.

PERRY, R.B. Economic value and moral value. The Quarterly Journal of Economics, v. 30, n. 3, p. 443-485, 1916.

RICARDO, D. On the principles of political economy and taxation. Memphis: General Books LLC, 2010. 498 p.

SAY, J.B. A treatise on political economy. vol. 1. Memphis: General Books LLC, 2010. 224 p.

SCREPANTI, E.; ZAMAGNI, S. An outline of the history of economic thought. Oxford: Oxford Scholarship Online, 2005.559 p.

SIMON, L.H. The values of nature. In: FREEMAN, A. M.; CORNELL, T. Valuing nature: a set of papers resulting from the Shipman Workshop. Brunswick: Bowdoin College, 2002. p. 69-96.

SMITH, A. An inquiry into the nature and causes of the wealth of nations. Hollywood: Simon \& Brown, 2011. 482 p.

TURNER, R.K. et al. Valuing nature: lessons learned and future research direction. Ecological Economics, Amsterdam, v. 46, n. 3, p. 493-510, Oct. 2003. 